\title{
REVENANTS IN OLD NORSE LITERATURE AS EMBODIED MEMORY
}

\author{
MARIE NOVOTNÁ
}

\begin{abstract}
Beings that come from the past into the present could be an example par excellence for memory studies. Revenants are an outstanding phenomenon of Old Norse literature that has been researched from many points of view: e.g. those of literary science, historical sociology, anthropology and history of religion. Their results are completely different as they ask different questions. In the first part of the article, statements about Old Norse revenants are ordered according to which of four Aristotle's causes they relate. Then, revenants are framed in the context of memory studies. It might offer a modest perspective, concentrating on memory, i.e. the context the story is set into. From that point of view, we can see a dialogue with a past version of a person, with what he brought to the world and what he left there, i.e. with memory. As it is mostly a disturbing past that revenants represent, they can be seen as literally embodying a problem that lies in (individual or cultural) memory. Within the saga genres, an important difference consists in whether the past a revenant haunts a man or a hero actively seeks the past.
\end{abstract}

Keywords: Old Norse sagas; revenants; memory studies

Old Norse revenants are a theme in which research has been interested since its beginnings. There are many hypotheses and results that differ according to the paradigms used. This article is aimed at formulating possible questions that could be asked in the framework of memory studies, trying to see revenants as bearers of memory. Beings that come from the past in the present could be an example par excellence of this discipline.

To be able to indicate some directions in which the approach of memory studies might go, numerous research theses concerning Old Norse revenants will be discussed. ${ }^{1}$ For the sake of structuring this overview of various hypotheses on Old Norse revenants existing in the secondary literature, Aristotle's causes will be used. In that way, I will draw attention to the paradigms always predetermining the statements, which seem otherwise to be incompatible with each other as they arise from completely different disciplines and

1 What differs among various conceptions is often the meaning of this verb "represent, symbolize, mediate" etc. 
approaches. From the large spectrum of secondary works on that topic, the most relevant for exploring what memory studies might add to existing views will be presented.

Because of a broad social spectrum of saga readers, including educated literary elite, a revenants' scene could have embodied various meanings - both literal and symbolic already in the Middle Ages. The broad variety of interpretations enumerated below might thus not be just caused by different disciplines and changing paradigms in the course of our scientific history. It might arise from the material itself, that contained a large spectrum of possible understandings of revenant stories, which were applied according to different variables as e.g. level of education, time of writing and genre of the text. ${ }^{2}$

From those variables, genre differences in the approach to revenants is the most evident one. In this contribution, examples from Íslendingasogur will be mentioned primarily (as most of the secondary literature has done) and the revenant Hrappr from Laxdoela saga will be used as an illustration. Finally, I will also mention other genres and briefly formulate a hypothesis how those bearers of memory change in different narrative modes. As in the case of all generalisations, contra-examples can always be found to all the statements, and due to the limited scope of the article, this enormous amount of material cannot be discussed in detail. Thus, the only aim of this article is to review different methodological possibilities and offer an inspiration for further research on Old Norse revenants.

\section{Causa finalis}

Let us first ask for what purpose revenants appear in the stories. This question might be answered by literary science - whether one asks in the framework of conscious authorship or an unconscious one, resulting from the oral tradition.

From that teleological point of view, revenants have been often argued to mediate contrast between the human and another world. They serve as a counterpart to the livings: their negative features have been understood as needed for a contrast to the radiant characters, their positive features (mainly in legendary sagas) as sources of things unavailable for ordinary people, such as wisdom or precious and magic objects (e.g. Kozák - Ratajová 22-23). On a more sophisticated narratological level, revenants (as other supernatural intervention) can be seen as causing a distortion of the balance in the narrative structure that has to be re-established in the course of the narrative (Korecká 13). Finally and in a very concrete way, their literary function has been formulated as the possibility for social mobility from the point of view of the revenants' antagonist. Revenants serve as obstacles to be beaten by a young hero of an undetermined status so that he gains or renegotiates his social status, in a kind of rite of passage into manhood (Kanerva 2013, 121-128).

This might be well illustrated in our case study, Laxdoela saga. Óláfr, the son of a slave woman although of Irish royal dynasty, is the fruit or product of an unapproved sexual relationship and as such he has a problematic position in the society. This can be heard e.g. in words of the legal wife of his father Hoqskuld that she pronounced before

2 It has been argued that saga authors used revenant episodes to illustrate ideas of humoral theories (Kanerva 2011, 23-24 and 2014, 229). 
Oláfr's departure to his new farm at Hrappstadir: "with his wealth the slave-woman's son should be able to make a name for himself." (LaxEN 34) ("Hefir ambáttarsonr sjá auð til pess, at uppi sé hans nafn.”) (LAX68, ch. 24). After visiting his Irish royal grandfather and thus gaining some self-confidence, Óláfr beats Hrappr. By that act, he puts himself to the linage with his father who was an authority for the local people helping them against Hrappr's violence already while he was alive:

- "Once again, the farmers called on Hoskuld to tell him of the difficulties Hrapp was causing and ask him to find some solution." (LaxEN 19)

"Nú var enn sem fyrr, at menn fóru á fund Họskulds og sogðu honum til peirra vandræða, er Hrappr gerir mǫnnum, ok biðja hann nokkut ór ráða.” (LAX 39, ch. 17)

In the final scene where Óláfr attacks Hrappr with his spear, his bravery is contrasting to the cowardice of the servant who fled in fear. Oláfr proves to be a respectable man and farmer -similar to Kjartan in Eyrbyggja saga, who is not the biological son of the master of the farm and obtains the status of the new master of the house at Fróða farm by defeating all the dead (Kanerva 2013, 32-37; EYR 152).

\section{Causa efficiens}

What was the reason that they came into the stories? What pushed them there? ${ }^{3}$ This question can be answered from the point of view of psychology or of historical sociology where sagas are mostly understood there as key for the understanding of the Old Norse society in the time of their writing down.

Revenants as acting figures have been interpreted as originating in the tensions in 13th century Iceland that was caused by new ways of functioning in the society. Liminal beings between worlds are thus a way to express the ambiguity of the time of sagas writing down and their destructivity and greed can be seen as an expression of the fear of chaos that threatened as the old system of inheritance was changing in the late 13th century (Merkelbach 194). As transgressors of boundaries, the revenants highlight the social and cultural norms incorporating "the societal fears and cultural anxieties concerning what happens if these norms and expectations no longer hold" (Merkelbach 203).

There are substantial differences among researches in the concretisation of what threats revenants might embody. Kanerva argues that the restless dead "function as indicators of social and moral conflicts" (Kanerva 2013, 44-45). ${ }^{4}$ One of those conflicts concern

This question is not meant in the context of the debate "oral vs. written" form of sagas, we stay in the framework of the preserved text and pose this Aristotelian question to them.

4 In Eyrbyggja saga, Kanerva identifies unspoken sins resulting from not following sexual norms as these conflicts. The results of such behaviour - offspring of indeterminate status without paternal support - causes mental and social disequilibrium. She considers e.g. seals that appear in connection with revenants to be the symbol of unproven sexuality (Kanerva 2013, 38-40). On the other hand, Merkelbach argues "that seals, sea mammals who can exist both in water and on land, are ambiguous creatures, belonging to two worlds and frequently crossing the boundary between them. Thus, the seal might be a suitable shape for the equally hybrid undead" (32). The motif of transgressing boundaries is common to both intepretations. 
socially unacceptable deeds that shake the established order - often sexually unapproved relationships. Another often mentioned conflict is that of religion: researchers point to the fact that revenants are presented as possessing pagan abilities that Christianity wants to supress - mostly greed and violence. Merkelbach sees their greed (i.e. not wanting to let go of their property) in a broader social and economic context. She points out that in revenants' interactions with the living, the focus is not on their action but on "the effect it has on the living" (38). Their economic destructivity thus highlights their "societal monstrosity" (42-43).

Focus on the property is especially prominent in Hrappr's case. Already before his death, he gives the last order so that he will be able to control everything:

- "I wish to be buried in the kitchen doorway. Have me placed in the ground upright, so I'll be able to keep a watchful eye over my home." (LaxEN 19)

“...vil eg mér láta grọf grafa í eldhúsdyrum, ok skal mik niðr setja standanda par í durunum; má ek pá enn vendilegar sjá yfir hýbýli mín.” (LAX 39, ch. 17)

Furthermore, all his activities after death are entirely aimed at preserving his property (Merkelbach 194). He also kills his own son to attain that goal, which is unique even among revenants. Hrappr's presence affects his son so much thathe "went insane after having lived there only a brief while and died shortly afterwards" (LaxEN 19) ("er hann hafði par litla hríð búit, pá tók hann œrsl ok dó litlu síðar”) (LAX 40, ch. 17).

Threats and anxieties on the psychological level have been as a cause for the revenants' stories identified by McKinnel. He argues that visits of a dead lover - a special type of revenant stories, frequent in ballad and folklore in general, but present also in Old Norse literature - mediate an individual trauma caused by the death of the closest person. He analyses Helgakviða Hundingsbana II, where dead Helgi, after Sigrún's longing for him, comes back to spent one night with her in the burial mound. Later, Sigrún dies due to grief and sorrow within a few days (Eddukvøði II 283). According to McKinnel, this is a solution for an insoluble situation: to die with her man was forbidden for the wife in the Christian context, but high-class women still felt a bad conscience for not having been sacrificed. Sigrún spends one night in the mound (representing a kind of symbolic burial, but not suicide) and then, in the very last prose commentary to the lay, she is said to have died of grief which was acceptable for the Christian ethic (McKinnel 229).

\section{Causa materialis}

What are revenants made of? What kind of body were they imagined to possess? We can be sure that they were not made of the molecules of modern science, but the concept of matter behind them differs also from the ghost stories of 13th century Continental Europe.

In line with the objectivist science of time, the nature of the Old Norse revenants has been the first question researchers of the 19th century had asked about this phenomenon. Most of them did not see any difference from the immaterial ghosts of the classical antiquity they were primary dealing with. It has changed with the Neckel's statement that 
"the heathen Germanic people did not know anything about having a soul that would live longer than their body. They were Pórstein or Gísli and as such they also survived their death, as physical men, as living corpses" (Neckel 37). Since that, the concept of so-called lebende Leiche has been used and it has been emphasised that the Old Norse revenants have extraordinary similarities with the living. Those similarities encompass all areas of corporeality - senses, feelings, and perceptions. ${ }^{5}$ They look like living people, they are at least as physical as living people (sometimes even more - they are stronger and heavier), they live (lifa) and die (deyja) with the same verbs as living beings and they also fear their second death. Their physical appearance is that of the corpse (it soon swells and become black), they share the sentiments of living men and they take their social status with them to the burial mound (Gould 176-178). The difference between revenants and the livings can be found more in the mental sphere. They are closer to magicians and to supernatural beings having abilities unavailable for usual people (such as foreseeing the future and other kinds of wisdom, affecting at a distance, controlling the natural elements, and having magical power in their eyes) but also disabilities as they do not speak naturally, their speeches being formalised and short (Klare 44).

Later research has also paid some attention to their materiality, inter alia while clarifying the terminology that shows problems with the word "ghost" because it is associated with an immaterial substance, as well as while defining the differences between Old Norse revenants and continental vampires sharing some of their physicality (Chadwick 50, Jakobsson 310). In other studies, corporality of Old Norse revenants has been mentioned as a distinctive feature of revenants (Kozák - Ratajová 7) and it has been pointed out that the corporality enhances their destructiveness and - "being intimately tied to their attachment to property - ... their reluctance to let go" (Merkelbach 194).

In Laxdoela saga, we find an interesting experiment about revenants' materiality. When Óláfr starts fighting against Hrappr, he disappears into the ground:

- "Olaf made a run at him, but Hrapp let himself sink back down to where he had come from, putting an end to their struggle. Olaf stood there with the spear shaft in his hand, for Hrapp had taken the blade...The following morning Olaf went to where Hrapp had been buried and had him dug up. Hrapp's body was perfectly preserved and Olaf found his spear blade there." (LaxEN 35)

"Óláfr vill pá renna á Hrapp, en Hrappr fór par niðr, sem hann var kominn; skilr par með peim; hafði Óláfr skaft, en Hrappr spjótið...Um morguninn eftir ferr Óláfr heiman ok par til er Hrappr hafði dysjaðr verið, ok lætr par til grafa. Hrappr var pá enn ófúinn. Par finnr Óláfr spjót sitt." (LAX 69, ch.24)

At the first glance, it might be considered as evidence of immateriality, but we have seen that the spear disappears too. Thus, they are equally material. This sinking into the ground might be a similar process to the emergence of a revenant described in detail in Eyrbyggja saga, where parts of Pórgunna's body (in the form of a seal) emerge gradually from the floor (EYR 147). Both episodes can be rather connected to revenants' magical abilities.

For numerous examples, see Klare. 


\section{Causa formalis}

Why do the revenants look as they do? What forms in the minds of Old Norsemen caused this? We have pointed out that the most striking feature of revenants is their physicality, so we will look for answers to the question "Why are they physical?". The discipline that tries to ask that might be the history of ideas.

Kanerva considers that saga revenants represent a specific way of conveying feelings and mind movements in a material form. This is similar to other oral cultures, where people conceptualize and categorize not distinguishing our ontological categories and preferring matter (Kanerva 2015, 120). Hasenfratz generalizes that close connection between the living and the dead, as well as an idea of the inseparability of the physical and the spiritual can be found in many archaic societies, due to the concept of collective mentality. In these societies, people are not interested in whether something (in our categories) is spiritual or material, but what power and effect it has. What works is real and thus the dead that are powerful are also real (Hasenfratz 5-6). ${ }^{6}$ Anthropological research shows that this feature of archaic thinking, not distinguishing the physical and the non-physical levels, can be encountered until today in the revenants' stories e.g. in Transcarpathian Ukraine (Cichá et al.).

Revenants thus might show the concrete way of thinking that demands a physical image even when expressing phenomena that in our point of view lie in the immaterial realm. ${ }^{7}$ In this view, revenants in Old Norse literature can be considered as a concretization of a negative thought or an emotion, or even expressions of mental disorder as they often occur in situations of emotional confusion associated with social or personal conflicts. They seem to be contaminating others with fear, illnesses or madness or even causing death (Kanerva 2012 and 2014).

In Laxdoela saga, we read that Hrappr "in his haunting he killed most of his servants" (LaxEN 19) ("hann deyddi flest hjón sín í aptrgǫngunni”) (LAX 39, ch.17) without any closer explanation, the mechanism had to be an evident possibility. In the above-cited passage Hrappr caused his son's madness followed by his death, there is a pronounced connection between the effect of the revenant, fear, and death. In the case of Óláfr, we have seen that stronger individuals could resist this effect, either by chasing revenants away or by not succumbing to the diseases associated with it. This ability is in Old Norse literature related to social status (Kanerva 2014, 227): as in many other socities, the upper classes do not show as many signs of fear but rather express anger that leads to action.

Diseases caused by the material dead can be thus understood as related to immaterial emotions (similarly to other diseases) while "caused" seems not to be a right verb since the mental and physical aspects are not separated (Novotná 2019, 54-58). Physical signs of emotion in Old Norse literature show that there is no fundamental gap between emotions and illnesses (Novotná 2018b, 61). Mind (hugr) that is the driving force of revenants

6 Hasenfratz relates revenants to the phenomenon of "toten Lebenden": people who live biologically but have already been ritually excluded from society and declared dead as they have no power any more. In an archaic society, life is a communion and whoever shares the communion, lives, independently of his/her biological situation (11).

7 That there is no fundamental gap between emotions and illnesses has been also proved on physical signs of emotion in Old Norse literature (Novotná 2018b, 61). 
is of material nature, too. It is anger what usually allows them to move even after death: in Old Norse literature, the afterlife is not a punishment as it is in continental literature, but a desire to continue to participate. They perform their revenant work either by their own will (often a persistent anger), by the will of the living, or they are passive followers of the will of a stronger revenant.

Indeed, we can abstract from other stories that predisposition to become a revenant is a strong mind, social inadaptability, authoritarianism, uniqueness or otherness in some, even in a physical sense. Hrappr is perfect example of an unpleasant man, strong minded and grumpy already in his lifetime. The first we read about him is that he "was disliked by most people, being overbearing to his neighbours" (LaxEN 9) ("Hrappr var flestum mǫnnum ekki skapfelldr, var hann ágangssamr við nábúa sína”) (LAX 20, ch. 10). The problems he had caused by this behaviour remained in the fabric of society and did not end with his death.

\section{Memory studies}

We have seen a broad spectrum of methods and questions that have been used to elucidate the phenomenon of revenants. Their answers seem to a great degree disparate and introducing approach of memory studies might help to show more connections among them. Some of the above-mentioned conclusions could be already framed as part of memory studies as the relationship between narration, society and history is one of the most central concerns of contemporary memory studies (Glauser 19). Merkelbach explicitly mentions revenants as "a past that was haunted, and perhaps haunting" while speaking historically about threatening the breakdown of patrilineal inheritance patterns in the late 13th century Iceland, as well as - in the association with paganism - "the pastness of the undead...the past is one that does not want to let go of the present” (195).

Nevertheless, if we look neither teleologically (what purpose it serves in texts, as literary science does), nor socio-historically (what it mirrors of the real conditions), the picture we might get from memory studies may have a slightly different focus. They offer a modest perspective as they are concentrating on a special context - memory being the context in which the story is set. In that framework, sagas are seen as snapshots of working memory, the exploration of social and ethic spaces, as communal identity negotiations where answers to important questions are always provisional due to number of subtle contingencies (Ranković 533). Revenants could be thus understood as one of conditions or obstacles that influence the flow of events, and for memory studies an important and specific one, as they themselves come from the past. ${ }^{8}$

Our question would thus be why the past enters the present and with what message. Memory as a "contemporized past" (Assmann 129) provides a focus on the memory of the past. In this context, a revenant represents memories of a person and his/her deeds and position in the society (thus, not the socio-historical reality). This memory is actively

8 The general loss of memory, on the other hand, is often depicted as tragic in Hans Christian Andersen's fairy tales, which intentionally imitate orality and folklore. It is fair to say, then, that the concept of memory has been severely challenged and contested since early modernity (Březinová 2019). 
shaped by its followers, i.e. the saga protagonists dealing with the revenant - mainly its relatives, but also other members of the society. They are reworking their relationship to the dead person, to its deeds and to its effects in the fabric of relations, exactly according to new cultural memory studies that stress the necessity of acting out a relationship to the past from a particular point in the present (Glauser 9).

The acting out a relationship to the past makes also the distinction between revenants and other supernatural beings more clear. All have been seen in a similar function as representatives of the other world: literary as a challenge to a character to show his courage and dauntlessness, or sociologically as an expression of anxiety in a changing society. It has been argued that the supernatural elements appear when a "confrontation between the present and the past is perceived" (Clunies Ross 450), and in the case of revenants, the connection with the past is the most pronounced and specific. In texts where revenants appear, we can see an active dialogue with a past version of the person, with what he/she brought to the world and what/she he left there, with that which remains from the person that died, i.e. with memory. Dialogueness of this process makes it clear that revenants are not only bearers of memory, but also creators of memory - as they are shaped by the present.

This dialogue of the past with the present is always problematic and ambiguous. Revenants are usually elements that are questioning the moral of the stories and both the literary and the socio-historical approaches have seen revenants as part of a disequilibrium. The disruptiveness of revenants does not have to lie only in active attacking the living. Merkelbach has shown that the group of revenants in Eyrbyggja and Flóamanna saga just make ordinary life impossible as they take the place of the living by the fire in the hall (EYR 150-152; FLÓAM 280-283). We can see how threatening the mere presence of the undead is. "The living can no longer interact among themselves, they can neither travel nor meet, and their living spaces become unusable when the undead occupy them. Revenants do not just destroy individuals, their kin, and servants: they also destroy the very fabric of society" (Merkelbach 195). Understanding revenants as the past that does not allow the present to live shows also their function as obstacles to economic activity "as they effectively do not let the next generation take over" (43). They represent a problematic past that occupies an important, central place in the present and has to be removed, reinterpreted in order to make the continuation of life possible. The present generation has to oppose the acting power of the past, i.e. revenants, take it into their hands and actively change its context. If a hero or society beats a revenant - i.e. gets rid of a problem of the past effecting the present - the equilibrium is restored.

In this moment, a positive function of revenants shows up. Their function from the literary point of view - a possibility of young heroes for social movement - appears on the social level as the contribution to the preservation of social norms. Since the characters always overcome the revenants, they play role as a conservative social force "reaffirming the stabilizing forces of societal bonds" (Merkelbach 203). Moreover, the message the revenants arrive with might not always be seen as a destructive one: e.g. Hrappr shows us that one should not sell his own land under its price: the mention that his former land has been sold below its price is a clear indicator that it will again appear to do something against this unfair act (LAX 40, ch.17). Ambivalent relations to the revenants are best uttered by the legendary sagas, as the reason for journeys to the past, i.e. for visiting the 
mound, is to gain something valuable both in the material or immaterial realm: treasures, powerful artefacts, fertility, wisdom or poetry (Kozák - Ratajová 19-20).

Nevertheless, to gain something positive of them, the revenants have to be overcome in most cases. How does that acting out and removing or reinterpretation of revenants happen? Useless (groups of revenants) or directly harmful (individual revenants) memories have to be forgotten or integrated to the system. The first possibility, trying to push the revenants away from the society of livings, i.e. liquidation of revenants, is described in many Íslendingasogur in detail and has to be understood as an important part of the revenant motif. Powers that are used to overpower the revenants are thus stabilizing forces, namely Christianity, laws or direct physical violence. Restoring borders consists of separating dead from the human community by transferring or fencing the grave; ${ }^{9}$ a physical fight with the revenant; cutting a revenant's head off and laying it on his back; and finally burning the corpse. Another possibility is the use of a court trial, Christian prayers and a cross (Klare 52-54). ${ }^{10}$ On the psychological level, if a woman is able to drive away a revenant, i.e. to separate from her memories, renew her integrity, she survives; otherwise, she is taken with him to death - overwhelmed by her memories. ${ }^{11}$

In the terms of the above-mentioned arguing about the materiality of emotions (causa materialis and formalis), we have seen revenants as materialised emotions as e.g. that of fear and as their moving force materialised emotions of anger or greed. In the framework of memory studies, the corporality of revenants may point to that also memory is a concrete, material entity. This memory, embodied or mediated by a revenant - acts, has its own will and motivations, can be killed, and can literally die. ${ }^{12}$

The dying out of a problematic piece of memory is thus a desired but very complicated act as we can see in the revenants' stories in Íslendingasogur. What we have called "restoring of the equilibrium in the plot" from the literary point of view might be from the point of view of memory studies called "forgetting". Memory studies write about forgetting as an important, selective, active, and complicated process. In that framework, the basic psychoanalytical dichotomy of suppression of memories vs. their processing might not be as dichotomist as usually considered. The forgetting (suppression) and integrating (processing) of memories represent actually the same process - if we only understand the destruction of revenants as re-integrating them into nature, "into the landscape where the revenant can be finally contained" (Merkelbach 45).

The origin of stories about revenants (causa efficiensis) could be understood from the point of view of memory studies in the same way as the origin of other folk beliefs. According to Lindow, encounters with the supernatural tend to occur to a person when

9 "Hoskuld ...went to Hrappstadir to disinter Hrapp and move him somewhere far away from sheep and men alike. Hrapp's haunting decreased considerably after this." (LaxEN 19) ("Họskuld ...lætr grafa upp Hrapp og fœra hann í brott, par er sízt væri fárgangr í nánd eða mannaferðir. Eftir petta nemast af heldr afturgǫngur Hrapps.") (LAX 40, ch. 17)

10 "Then he had a large bonfire prepared, Hrapp's body burned and his ashes taken out to sea. No one else was harmed by Hrapp's haunting after that." (LaxEN 35) (“Síðan lætr hann gera bál; er Hrappr brenndr á báli, ok er aska hans flutt á sjá út. Héðan frá verðr engum manni mein að aptrgǫngu Hrapps.") (LAX 69, ch. 24)

11 An example of the latter case is above-mentioned Sigrún in Helgakviða Hundingsbana II, former cases can be found in many ballads (McKinnel 230).

12 In terms of Lockett's use of terminology of cognitive linguistics, forgetting as actual dying of memory is not at that stage a literary metaphor but a conceptual one (Lockett 2011). 
cultural norms are at stake and the person is under some kind of stress. Those individual experiences have then been interpreted through cultural norms and traditions, i.e. through collective memory (Lindow 508-509). Thus, individual experience in stressing circumstances ${ }^{13}$ could be interpreted using known revenant stories and then distributed widely through communicative memory in the society. That these experiences are easy to spread might be reflected in the known contagion of revenants, not only the Old Norse ones (if someone sees a revenant, in many cases he dies soon after, whether this is a close relative or a stranger). ${ }^{14}$ Expected and extreme experiences spread easily - those stories are contagious.

Extreme experiences are not only quickly communicated in a society, but also on the individual level, they tend to be remembered more than other events. Emotions are closely related to memory also according to modern science as neural networks activated in the remembering process are closely inter-related with emotion systems, and trauma as a situation where individual memory is highly activated has been described also in Old Norse literature (Larrington 514-515). From the psychotherapeutic point of view, specifics of memory's functioning while experiencing a trauma has been identified in Old Norse sagas (Tulinius 498). In the revenant stories, we can also detect a sign of reports about traumatizing events: fragmentation, the intermittency, and speech jitter. We have seen that there is no difference between revenants and living people on the physical level, but specificity could be found in the mental sphere - in particular in the speech of revenants. We see there the typical characteristics of memory traces of traumatic events where normal memory processing disintegrates and dissociated fragments appear instead (Tulinius 496). The speech of revenants tends to be short, formalized or stylized, simply alliterated or structured by rhythm; sometimes being a complete skaldic stanza in a concrete metre. This formalism might associate the detached nature of a traumatic experience.

\section{Genre differences}

We can conclude that revenants literally can embody a problem that lies in memory - and whether the focus lies in an individual memory or cultural one, differs in the degree among genres, as well as concretisations of the problem revenants embody and its solution. So, from the point of view of memory studies, we might express also genre differences in presenting revenants.

We have mentioned that sagas work with revenants in the context of collective memory: they are indicators of a social problem, and in course of the saga, this disequilibrium is solved, revenants beaten and order re-established. The heroic lays, on the other hand, is a genre that shows extreme ends of extreme decisions and as such has to end tragically. In the context of revenants as bearers of memory, its specificity could be expressed so that it is more concerned with the individual memory - the psychology of a person is thematised, the focus being on his/her fate. That is why in this genre, researchers use psycho-

13 While analysing encounters with a troll, Lindow talks about "pour perceptual conditions" (509). In the case of revenants, mostly emotional stress has to be taken into consideration.

14 Merkelbach 44; EYR 96. 
logical reasoning more often. The revenant can represent such a strong afterthought that it draws the person close to the dead one, sometimes causing also even his/her death - as is the typical case of visit of the dead lover in ballads (Novotná 2018a,297). Besides the focus on the individual memory, we see thus also that in heroic epic, revenants embody another, but equally powerful emotions - memories or longing for the lover instead of the sagas' fear.

In the example of Helgakviða Hundingsbana II as well, Helgi's return could be understood in terms of Sigrún's individual memory as McKinnel's psychological explanation suggests - a dilemma caused by two moral norms (i.e. pagan human sacrifices vs. Christian ethics) and an understandable grief for a beloved man. The feelings of Sigrún are described as perverted or at least ambivalent - her longing for her lover is portrayed as ravens' longing for meat etc. (McKinnel 230). This is not a normal poetics of a love song, but it can be understandable in terms of psychology, after traumatizing experiences of the deaths of her relatives and lover. Nevertheless, the heroic epic can also be framed in terms of cultural memory: Sigrún's loyalty with the family has been broken, her closest relatives were killed because of her and she has cursed her brother. No wonder that Helgi, representing the problematic past, has to return. But in contrast to sagas, the solution is the death of the living woman, not of the revenant. Sigrún as the source of the problem dies and the problem with her. No other way of regaining the social equilibrium, of integrating the past into the present or repulsing it, are at hand at that moment. So, although the focus lies on the individual experience, the memory of the society is there as the source of the individual tragedy, as an inseparable background without which the story would not have taken place. The disequilibrium in the memory of the society - the killing of the beloved wife's closest relatives - is coming back as a revenant, taking the last main actor of the tragedy with him into death.

If we try to distinguish between various saga genres in the question of revenants, the main difference is between the wandering revenants and the dweller of a mound haugbúi. In classical sagas of Icelanders, the genre that most of the above-mentioned studies analyse, the typical revenant is actively haunting people. Just very few revenants in this genre inhabit a mound and even those come out of their mound and haunt. ${ }^{15}$ In legendary sagas, on the other hand, mostly haugbúi appear. As they do not go out of their mound, contact with them is usually initiated by living beings, by a hero. Usually, the haugbúi does not give his property voluntarily, but many sagas describe how his good side - the will to let the living take over - and the bad one - the will to possess, the will to power - is wielded with different results. ${ }^{16}$

Past that is coming to us unwillingly, i.e. revenants haunting in sagas of Icelanders, is pulled away by restorers of order, by strong personalities or just by their closest relatives. If you are haunted by an unwanted past, you pull it away. We have seen physical processes of destroying the revenant that represents the processes of forgetting for us. In legendary

15 An exception is Gunnarr from Njáls saga. He announces his presence by singing in the mound and attracts through that attention to the fact that he needs to be revenged. Nevertheless, he is also acting in line with other revenants of sagas of Icelanders as the past is actively going with a message to the people: he initiates the contact with the living himself.

16 For example, in Hervarar saga, Hervor's dead father finally gives her the sword she is asking for, but after a long inner struggle that is mirrored in their long dialogue in the mound. This psychological struggle of the revenant shows the ambivalent relationship of the living to their dead (Kozák 18-20). 
sagas, the situation is a different one. There, people are more active in their relation to the past, they seek the revenants themselves; they are interested in what the past can give them, in the treasures or wisdom they can obtain from the revenants.

A genre difference in handling revenants can also be seen between classical and post-classical sagas of Icelanders. The post-classical ones show a substantial degree of narratological sophistication (Korecká 23). Putting aside for now the question whether and how it reflects the political and social changes in the society of 13th and 14th century Iceland, we can ask how these genre differences in narrations about revenants reflect different approaches to the past. We could hypothesise that the more sophisticated work with the narratological modes in post-classical sagas might reflect the more conscious position of the author ${ }^{17}$ and a bigger distance from the created text, i.e. from the processed matter, i.e. from the past as such.

There is a fundamental difference between whether the past haunts a man or a hero actively seeks the past. The active search for revenants (which we find in some post-classical sagas of Icelanders and in many legendary sagas) is an active confrontation with the past. To be able to do this, one has to have a distance from it, to see past as a separate entity from himself. Changes in culture memory means that the way of conceptualising world changes and we can see that past as a separate entity emerging.

\section{Conclusion}

In terms of memory studies, revenants can be understood as memories or traces left by people that did not end their activity in the world with a peaceful, reconciled death. They did not manage to part with their power or they died at a young age, and their incomplete actions have been hanging in the air - whether in the perception of their closest relatives or of a wider society.

To die means to separate from this world, to give up things, ideas, desires, and this process has been going on throughout life, from early childhood. Individual development is never undisturbed, and giving up omnipotence in childhood as well as acknowledging the loss of potency at the end of adult age or of mental and physical abilities in old age is a painful process against which individuals with strong will can fight for a longer time. However, it is a lost struggle with a self-destructive effect. Some saga revenants succeed in overcoming their greed and cupidity at least face to face with their children (giving them treasures from the mound or at least not harming them), others do not.

Those people, resisting death and the losses associated with it, resist also life, as the life does not exist without death. Revenants can thus embody a deep connection between life and death, whether they are perceived on a personal, social, psychological or economic level and their role in the Old Norse literature shows that the physical death is not at all the end of one's presence in this world. ${ }^{18}$

17 That formal sophistication brings about consciousness of authorship e.g. skaldic poetry.

18 The work was supported by the Ministry of Education, Youth and Sports - Institutional Support for Longterm Development of Research Organizations - Charles University, Faculty of Humanities. It is an outcome of the project "University Centre of Excellence for Study of the Ancient and Medieval Thought Tradition” (UNCE 204053). 


\section{BIBLIOGRAPHY}

Assmann, Jan. "Collective Memory and Cultural Identity." New German Critique 65 (1988): 125-133.

Bayerschmid, Carl F. "The Element of the Supernatural in the Sagas of Icelanders." Scandinavian Studies: Essays Presented to Henry Goddard Leach. Ed. Carl F. Bayerschmid, and Erik J. Friis. Seattle: University of Washington Press, 1965. 39-53.

Březinová, Helena. "A Community Incommunicado. On Troubled Communication in Hans Christian Andersen's Fairy Tales." Hans Christian Andersen and Community. Odense: University Press of Southern Denmark, 2019. 35-57.

Chadwick, Nora K. "Norse Ghosts." Folklore 57/2 (1946): 50-65.

Cichá, Martina et al. „Nábožensko-mytologické představy obyvatel ukrajinského Polesí a Zakarpatí na příkladu víry v revenanty." Česká antropologie 65/1 (2015). 11-18.

Clunies Ross, Margaret. "Realism and the Fantastic in the Old Icelandic Sagas." Scandinavian Studies 74 (2002). $443-54$.

Glauser, Jürg, Pernille Hermann, and Stephen Mitchell. "Pre-Modern Memory Studies: An Introduction." Handbook of Pre-Modern Nordic Memory Studies. Ed. Jürg Glauser, Pernille Hermann, and Stephen A. Mitchell. Berlin/Boston: De Gruyter, 2018. 1-31.

Gould, Chester N. "They Who await the Second Death. A Study in Icelandic Romantic Sagas." Scandinavian Studies 9 (1926-27): 167-201.

Gottschling, Bernhard. Die Todesdarstellungen in den Íslendingasogur. Frankfurt, Bern, New York: Peter Lang, 1986.

Hasenfratz, Hans-Peter. Die Toten Lebenden. Leiden: Brill, 1982.

Jakobsson, Ármann. "Vampires and Watchmen: Categorizing the Mediaeval Icelandic Undead." Journal of English and Germanic Philology 110 (2011): 281-300.

Kanerva, Kirsi. "The Role of the Dead in Medieval Iceland: A Case Study of Eyrbyggja saga." Collegium Medievale 24 (2011). 23-49.

Kanerva, Kirsi. "Ógafa (misfortune) as an Emotion in Thirteenth-Century Iceland." Scandinavian Studies 84/1 (2012). 1-26.

Kanerva, Kirsi. "Messages from the Otherworld: The Roles of the Dead in Medieval Iceland." Deconstructing Death: Changing Cultures of Death, Dying, Bereavement and Care in the Nordic Countries. Ed. Michael Hviid Jacobsen. Odense: University Press of Southern Denmark, 2013. 111-130.

Kanerva, Kirsi. "Disturbances of the Mind and Body: The Effects of the Living Dead in Medieval Iceland." Mental (dis)Order in the Later Middle Ages. Ed. Sari Katajala-Peltomaa and Susanna Niiranen. Later Medieval Europe 12. Brill: Leiden 2014. 219-242.

Kanerva, Kirsi. Porous Bodies, Porous Minds: Emotions and the Supernatural in the Íslendingasogur, disertační práce, University of Turku, 2015.

Korecká, Lucie. "Narrative modes, narrative space, and narrative play in the post-classical sagas and poettir of Icelanders." Acta Universitatis Carolinae - Philologica 2019/3 (2019). 9-26.

Kozák, Jan, and Kateřina Ratajová. „Funkce mohyl podle staroseverských ság.“ Archeologické rozhledy 60/1 (2008). 3-35.

Klare, Hans-Joachim. "Die Toten in der altnordischen Literatur." Acta Philologica Scandinavica 8 (1933-34). $1-56$.

Larrington, Carolyne. "Emotions." Handbook of Pre-Modern Nordic Memory Studies. Ed. Jürg Glauser, Pernille Hermann, and Stephen A. Mitchell. Berlin/Boston: De Gruyter, 2018. 514-518.

Lindow, John. "Folk Belief." Handbook of Pre-Modern Nordic Memory Studies. Ed. Jürg Glauser, Pernille Hermann, and Stephen A. Mitchell. Berlin/Boston: De Gruyter, 2018. 508-513.

Lockett, Leslie. Anglo-Saxon Psychologies in the Vernacular and Latin Traditions. Toronto: University of Toronto Press, 2011.

Merkelbach, Rebecca. Monsters in Society. Alterity, Transgression, and the Use of the Past in Medieval Iceland. Berlin/Boston: De Gruyter, 2019.

McKinnel, John. Meeting the Other in Norse Myth and Legend. Cambridge: Brewer, 2005.

Neckel, Gustav. Walhall. Studien über germanischen Jenseitsglauben. Dortmund: Ruhfus, 1913. 
Novotná, Marie. "Role of the Body - Scandinavian Ballads vs. Old Norse Literature." Ballads. New approaches. Ed. Malan Marnersdóttir et al. Tórshavn: Faroe University Press, 2018a. 293-305.

Novotná, Marie. „Psychosomatické jevy v staroseverské literatuře." Revue pro psychoanalytickou psychoterapii a psychoanalýzu 20 (2018b). 48-64.

Novotná, Marie. Pojetí těla v staroseverské literatuře. Praha: Herrmann a synové, 2019.

Ólason, Vésteinn. "Dialogues with the Past." Handbook of Pre-Modern Nordic Memory Studies. Ed. Jürg Glauser, Pernille Hermann, and Stephen A. Mitchell. Berlin/Boston: De Gruyter, 2018. 489-494.

Ranković, Slavica. "Remembering the Future." Handbook of Pre-Modern Nordic Memory Studies. Ed. Jürg Glauser, Pernille Hermann, and Stephen A. Mitchell. Berlin/Boston: De Gruyter, 2018. 526-535.

Tulinius, Torfi. "Trauma." Handbook of Pre-Modern Nordic Memory Studies. Ed. Jürg Glauser, Pernille Hermann, and Stephen A. Mitchell. Berlin/Boston: De Gruyter, 2018. 495-501.

\title{
Primary Sources
}

Eddukvoeði II. Eds. Jónas Kristjánsson and Vésteinn Ólasón. Reykjavík: Hið íslenzka fornritafélag, 2014.

EYR: Eyrbyggja saga. Eds. Einar Ól. Sveinsson and Matthías Pórðarson. Íslenzk Fornrit 4. Reykjavík: Hið íslenzka fornritafélag, 1935.

FLÓAM: Flóamanna saga. Eds. Pórhallur Vilmundarson and Bjarni Vilhjálmsson. Íslenzk Fornrit 8. Reykjavík: Hið íslenzka fornritafélag, 1991.

LAX: Laxdoela saga. Ed. Einar Ól. Sveinsson. Íslenzk Fornrit 5. Reykjavík: Hið íslenzka fornritafélag, 1934.

LaxEN: The Saga of the People of Laxardal. Trans. Keneva Kunz. The Complete Sagas of Icelanders V. Reykjavik: Leifur Eiríksson Publishing, 1997.

\author{
Marie Novotná \\ Charles University \\ marie_nov@seznam.cz
}

